\title{
Effect of Diet-Induced Sodium Deficiency on Normal and Compensatory Growth of the Lung in Young Rats ${ }^{1}$
}

\author{
KEITH J. GALLAHER, ELLEN WOLPERT, STEVEN WASSNER, AND D. EUGENE RANNELS \\ Department of Pediatrics, Divisions of Newborn Medicine [K.J.G.] and Nephrology [S.W.J, and Department of \\ Cellular and Molecular Physiology [E.W., D.E.R.]. The Pennsylvania State University, The Milton S. Hershey \\ Medical Center, Hershey, Pennsylvania 17033
}

\begin{abstract}
Sodium deficiency is associated with decreased muscle growth and protein synthesis. We investigated the influence of diet-induced sodium deficiency on the rate and extent of compensatory growth of the right lung after left pneumonectomy in young rats of $83 \pm 1 \mathrm{~g}$ body weight. Starting 1 wk before surgery, all rats were fed a diet deficient only in sodium $\left(2-9 \mu \mathrm{mol} \mathrm{Na}{ }^{+} / \mathrm{g}\right.$ of food) ad libitum. Sodium-deficient rats were supplied with distilled water, whereas sodium-replete controls were supplied water containing $37 \mathrm{mM} \mathrm{NaCl}$. After $7 \mathrm{~d}$ on the experimental diets, both groups were divided and subjected either to sham thoracotomy (Sham) or to left pneumonectomy (PNX). Somatic growth and both normal and compensatory growth of the lungs were assessed 3, 4, and $7 \mathrm{~d}$ later. Sodium-deficient animals grew more slowly than control animals. In control PNX rats, right lung weight to body weight ratio ( $\mathrm{LW} / \mathrm{BW}$ ) increased to equal that of the combined $\mathrm{LW} / \mathrm{BW}$ in control Shams by postoperative $\mathrm{d} \mathbf{4}$, and remained at the Sham combined $L W / B W$ value on postoperative $\mathrm{d} 7$. Compensatory lung growth was less rapid in sodium-deficient PNX animals. At postoperative d 4, right $\mathrm{LW} / \mathrm{BW}$ was low relative to combined $\mathrm{LW} / \mathrm{BW}$ of sodium-deficient Shams. This ratio approached but did not reach the sodium-deficient Sham combined LW/BW value by $d 7$. Sodium deficiency thus reduced the rate of compensatory growth of the right lung. RNA/g dry tissue and RNA/DNA were low in sodium-deficient lungs relative to control at $\mathrm{d} 0$ and 7 but during the rapid phase of compensatory growth (d 3 and 4), both groups responded with a $20 \%$ increase in tissue RNA concentration. Similar protein/DNA ratios between PNX and Sham-operated animals in both sodium-deficient and control groups, along with elevated total DNA content in the right lung of both PNX groups, suggest that the compensatory growth was hyperplastic rather than hypertrophic. Our study demonstrates that diet-induced sodium deficiency decreases somatic growth and slows the compensatory growth of the right lung after PNX. (Pediatr Res 28: 455-459, 1990)
\end{abstract}

\section{Abbreviations}

$\mathrm{NaD}$, sodium deficient

Con, sodium-replete control

Received March 27. 1990; accepted June 18, 1990

Correspondence and reprint requests: Keith J. Gallaher, M.D., Division of Neonatology, Cape Fear Valley Medical Center, P.O. Box 2000, Fayetteville. NC 28302

Supported by a grant-in-aid from the American Heart Association with funds contributed in part by the AHA Pennsylvania Affiliate and by HL-20344 from the National Heart. Lung, and Blood Institute of the National Institutes of Health. K.J.G. is a recipient of National Research Service Award no. HL07589.

' Presented in part at the 1990 World Conference on Lung Health. Boston. MA. Mav 1990.
PNX, left pneumonectomy

Sham, sham thoracotomy

LW, dry lung weight

BW, body weight

Bronchopulmonary dysplasia is a common form of pulmonary dysfunction that is observed in as many as $20 \%$ of infants under $1500 \mathrm{~g}$ birth weight (1). It is now known that the pathogenesis of chronic lung disease in the neonatal period is related not only to the acute lung injury, but also to the ability of the infant to heal adequately. This in turn is influenced to a great extent by nutritional factors (2). Undernutrition increases the mortality rate of newborn rats exposed to hyperoxia (3), and may permanently affect lung structure. Rodents deprived of food for the first $21 \mathrm{~d}$ have a permanent reduction in the number of lung cells as assessed by lung DNA measurements and a permanent reduction in lung RNA $(4,5)$.

Electrolyte abnormalities also are common in neonates, especially those with chronic cardiopulmonary distress. These infants are often treated by restricting salt and water intake and administering diuretics (6-8), occasionally leading to sodium deficiency (9). Sodium deficiency has been associated with poor growth in both animals $(10,11)$ and humans (12). Wassner (10) showed that rats fed a diet deficient in sodium demonstrate delayed growth in terms of both weight gain and length, despite comparable caloric intake. This was associated with only mild hyponatremia (134 versus $139 \mathrm{mmol} / \mathrm{L})$ and with marked urinary sodium conservation. The $\mathrm{NaD}$ animals also had lower tissue RNA concentrations and exhibited decreased rates of skeletal muscle protein synthesis relative to sodium replete controls. This raises the issue of whether changes in sodium balance may modulate growth and development of the lung.

Partial pneumonectomy in the young rat provides a welldescribed laboratory model of rapid lung growth $(13,14)$. After partial resection of the lung, there is a rapid restoration of tissue mass so that the remaining lung mass equals that of both lungs in Sham-operated animals (15). Increased total DNA in the right lung and normal protein/DNA ratios, along with morphometric studies (16), suggest that this response results from cellular hyperplasia rather than hypertrophy. To determine the influence of sodium balance on lung growth, the rate and extent of compensatory growth of the right lung after PNX was investigated in young rats fed an $\mathrm{NaD}$ but otherwise nutritionally complete diet.

\section{MATERIALS AND METHODS}

Four-wk-old male Sprague-Dawley rats weighing $83 \pm 1 \mathrm{~g}$ (Charles River Laboratories, Wilmington, MA) were randomly 
allocated to two groups and housed seven to 11 rats per cage. Both groups received the same NaD test diet (no. 170950 Teklad, Madison, WI). This formulation provides between 2 and $9 \mu \mathrm{mol}$ sodium/g diet and previous studies have calculated a sodium intake of between 25 and $115 \mu \mathrm{mol}$ of sodium/d (10). The experimental group $(\mathrm{NaD})$ drank distilled water, whereas the control group (Con) was provided $37 \mathrm{mM} \mathrm{NaCl}$. Rats were weighed weekly or at surgery and snout to tip of tail length was measured to the nearest $0.1 \mathrm{~cm}$ with the rats lightly sedated with methoxyfluorane. Previous studies have shown that by the end of the 1st wk on study diet, the $\mathrm{NaD}$ animals demonstrated slower somatic growth (10). Rats have been maintained on the study diet for at least $3 \mathrm{wk}$ with no increase in mortality over that of the control animals (Wassner $\mathrm{S}$, unpublished observations).

At age $5 \mathrm{wk}$, after eating the test diets for $7 \mathrm{~d}, \mathrm{NaD}$ and Con rats were again randomly divided into two subgroups: PNX and Sham. Surgery was performed as previously described (17). Before surgery, the rats were anesthetized with $7.2 \%$ chloral hydrate $(0.3-0.5 \mathrm{~mL} / 100 \mathrm{~g})$ injected intraperitoneally. The left lung was exposed through a $1-\mathrm{cm}$ intercostal incision, tied at the hilum with a silk ligature, and excised. The ribs were reapproximated with 3-0 silk and the skin closed with stainless steel wound clips. The right lung was reinflated and external pressure was applied to the thorax to clear the remaining air. Sham operations were conducted similarly without actual lung resection.

Rats were maintained on the test diets until being killed on the day of surgery, or at 3,4 , and $7 \mathrm{~d}$ postoperative. After intraperitoneal injection of sodium pentobarbital $(5 \mathrm{mg} / 100 \mathrm{~g})$ animals were weighed and snout to tip of tail length recorded. Animals were exsanguinated from the abdominal aorta to minimize the blood content of the lungs. The lungs were removed rapidly, rinsed in cold $0.15 \mathrm{M} \mathrm{NaCl}$, blotted, and trimmed free of large airways. The left lung or entire right lung was frozen between blocks of aluminum cooled in liquid nitrogen; the tissues were subsequently stored at $-70^{\circ} \mathrm{C}$.

Frozen lungs were weighed and pulverized in a porcelain mortar cooled to the temperature of liquid nitrogen. A weighed sample, approximately $100 \mathrm{mg}$ of the resulting powder, was dried in an oven to constant weight, for determination of dry-to-wet weight ratio. An additional weighed aliquot $(100-200 \mathrm{mg})$ of lung powder was homogenized in $5 \mathrm{~mL}$ of ice cold glass distilled water using a polytron (PE-10) homogenizer. This homogenate was used for analysis of protein (18), DNA-phosphate (19), and RNA (20) as detailed previously (17). Calculation of the RNA content of the lung tissue was based on the assumption that 1 $\mathrm{mg}$ hydrolyzed $\mathrm{RNA} / \mathrm{mL}$ gave an absorbance of 31.25 at 260 $\mathrm{nm}$ in a $1-\mathrm{cm}$ light path (20).

Urine and serum samples were obtained on postoperative d 4 to confirm that the animals demonstrated laboratory evidence of sodium deficiency. Urine sodium and potassium were determined using a flame photometer (Instrumentation Laboratories, Lexington, MA) Serum urea nitrogen and creatinine levels were determined using commercial kits no. 640-A and 555-A, respectively (Sigma Chemical Co., St. Louis, MO). Because serum sodium values have been described previously $(10,11)$ and add little to the confirmation of the sodium-deficient state, they were not measured in this study.

Results are reported as mean \pm 1 SEM. Statistical analysis was aided by the use of computer statistical software (Stat View 512 +, BrainPower Inc., Calabasas, CA). Overall differences between grouped means were detected using one-way analysis of variance $p \leq 0.05$. If group means were determined to be significant by analysis of variance, differences between individual pairs of means were determined by the method of least significant difference (21).

\section{RESULTS}

Our study confirms earlier findings that evaluated the effect of sodium deficiency on somatic growth. Despite comparable ca- loric intake (10), NaD animals grew more slowly than the Con animals. BW of $\mathrm{NaD}$ animals was reduced after $7 \mathrm{~d}$ on the study diet (Table 1) and body length after $10 \mathrm{~d}$ (not shown). The results from urine electrolytes as well as serum urea nitrogen and creatinine evaluations were consistent with mild intravascular volume contraction in the $\mathrm{NaD}$ animals (Table 2). Urine sodium was negligible and urine potassium was significantly elevated in $\mathrm{NaD}$ animals versus control, suggesting a response that involved aldosterone release appropriate for the volume contraction. Both serum urea nitrogen and creatinine levels were significantly higher in the $\mathrm{NaD}$ group, suggesting volume contraction secondary to sodium depletion. These results are in agreement with the findings in the previous study by Wassner (10) and confirm that the NaD animals were indeed $\mathrm{NaD}$ relative to the controls.

With one minor exception, tissue dry-to-wet weight ratios were comparable between all groups of $\mathrm{NaD}$ and Con animals (Table 1), suggesting that the differences noted between BW and tissue weights do not likely represent significant differences in total body water content between groups. Previous determinations of extracellular water content using inulin have shown that changes in extracellular water account for a weight difference of only about $4 \%$ between $\mathrm{NaD}$ and Con animals (10).

During the intervals evaluated in our study, despite the changes in BW, sodium deficiency did not reduce normal lung growth significantly. This resulted in a tendency for the LW/BW ratio to be elevated (Fig. 1), although not to a statistically significant

Table 1. Effect of sodium deficiency on body wt, dry lung mass, and dry-to-wet ratio*

\begin{tabular}{|c|c|c|c|c|c|c|}
\hline $\begin{array}{l}\text { Treatment } \\
\text { group }\end{array}$ & & $\begin{array}{l}\text { Days } \\
\text { after } \\
\text { PNX }\end{array}$ & $\begin{array}{l}\text { Body wt } \\
\text { (g) }\end{array}$ & $\begin{array}{l}\text { Lung dry/ } \\
\text { wet } \times 100\end{array}$ & $\begin{array}{l}\text { Right lung } \\
\text { dry mass } \\
\text { (mg) }\end{array}$ & $\begin{array}{l}\text { Total lung } \\
\text { dry mass } \\
(\mathrm{mg})\end{array}$ \\
\hline Con & 6 & 0 & $118 \pm 2$ & $19.3 \pm 0.2$ & $89.5 \pm 6.1$ & $135.9 \pm 5.8$ \\
\hline $\mathrm{NaD}$ & 6 & 0 & $104 \pm 1 \dagger$ & $20.0 \pm 0.4$ & $86.4 \pm 4.7$ & $141.4 \pm 3.8$ \\
\hline Con Sham & 6 & 3 & $129 \pm 4$ & $19.7 \pm 0.1$ & $91.9 \pm 2.1$ & $139.2 \pm 3.4$ \\
\hline Con PNX & 6 & 3 & $130 \pm 3$ & $19.2 \pm 0.4$ & $104.6 \pm 6.2 \ddagger$ & \\
\hline $\begin{array}{l}\mathrm{NaD} \\
\text { Sham }\end{array}$ & 5 & 3 & $104 \pm 3 \dagger$ & $20.4 \pm 0.2$ & $76.6 \pm 1.2 \dagger$ & $117.9 \pm 1.7 \dagger$ \\
\hline NaD PNX & 6 & 3 & $99 \pm 6$ & $19.2 \pm 0.6$ & $87.9 \pm 4.2 \ddagger$ & \\
\hline Con Sham & 4 & 4 & $133 \pm 5$ & $18.7 \pm 0.4$ & $86.7 \pm 7.4$ & $132.6 \pm 11.0$ \\
\hline Con PNX & 5 & 4 & $125 \pm 6$ & $18.2 \pm 0.4$ & $128.2 \pm 7.2 \ddagger$ & \\
\hline $\begin{array}{l}\mathrm{NaD} \\
\text { Sham }\end{array}$ & 5 & 4 & $100 \pm 3 \dagger$ & $19.8 \pm 0.2 \dagger$ & $76.6 \pm 3.5$ & $116.4 \pm 5.6$ \\
\hline NaD PNX & 5 & 4 & $116 \pm 6 \ddagger$ & $18.2 \pm 0.2 \ddagger$ & 104.0 & \\
\hline Con Sham & 4 & 7 & $159 \pm 10$ & $20.7 \pm 1.8$ & $105.3 \pm 9.0$ & $163.1 \pm 16.1$ \\
\hline Con PNX & 5 & 7 & $156 \pm 3$ & $20.6 \pm 1.0$ & $152.1 \pm 9.1 \ddagger$ & \\
\hline $\begin{array}{l}\mathrm{NaD} \\
\text { Sham }\end{array}$ & 7 & 7 & $133 \pm 3 \dagger$ & $21.9 \pm 0.6$ & $96.3 \pm 3.0$ & $145.0 \pm 5.7$ \\
\hline NaD PNX & 9 & 7 & $118 \pm 3 \ddagger$ & $21.7 \pm 0.7$ & $115.6 \pm 4.9 \ddagger$ & \\
\hline
\end{tabular}

$*$ Values reflect mean $\pm 1 \mathrm{SEM}$

$\dagger p<0.05 ; \mathrm{NaD}$ vs. Con.

$\ddagger p<0.05 ;$ PNX vs. Sham.

Table 2. Serum and urine values in NaD and Con rats*

\begin{tabular}{ccccc}
\hline & $\begin{array}{c}\text { Serum urea } \\
\text { nitrogen } \\
(\mathrm{mmol} / \mathrm{L})\end{array}$ & $\begin{array}{c}\text { Creatinine } \\
(\mu \mathrm{mol} / \mathrm{L})\end{array}$ & $\begin{array}{c}\text { Urine Na } \\
(\mathrm{mEq} / \mathrm{L})\end{array}$ & $\begin{array}{c}\text { Urine K } \\
(\mathrm{mEq} / \mathrm{L})\end{array}$ \\
\hline $\mathrm{Con}$ & $4.4 \pm 0.2$ & $56.7 \pm 4.4$ & $35 \pm 9.7$ & $177 \pm 33$ \\
$\mathrm{NaD}$ & $7.6 \pm 0.7 \dagger$ & $75.1 \pm 8.0$ & $0 \ddagger$ & $322 \pm 29$ \\
& $p<0.001$ & $p<0.05$ & $p<0.002$ & $p<0.005$ \\
\hline
\end{tabular}

* Urine electrolytes, serum urea nitrogen, and serum creatinine measurements were made on samples obtained from animals killed on postoperative $\mathrm{d} 4$.

$\dagger$ Mean \pm 1 SEM; $(n=10$; PNX and sham combined).

$\mp$ Less than $5 \mathrm{mEq} / \mathrm{L}$. 

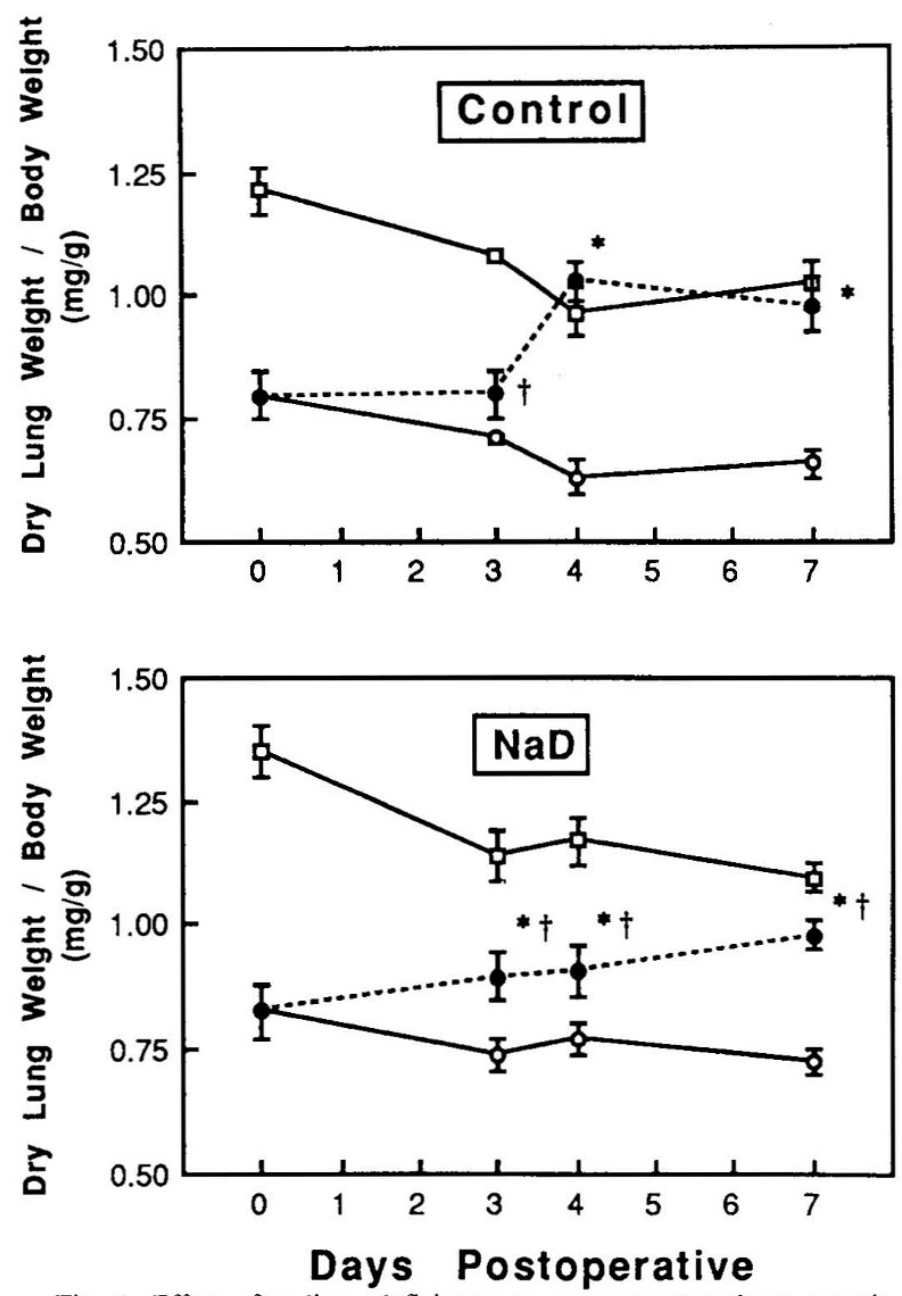

Fig. 1. Effect of sodium deficiency on compensatory lung growth. $\mathrm{LW} / \mathrm{BW}$ ratio is plotted vs age. Top panel represents values from Con animals and bottom panel from $\mathrm{NaD}$ animals. Right $\mathrm{LW} / \mathrm{BW}$ is represented by open circles, combined LW/BW by open squares, and right $\mathrm{LW} / \mathrm{BW}$ from pneumonectomized animals by closed circles. Right LW/ $\mathrm{BW}$ in pneumonectomized rats is significantly greater than right $\mathrm{LW} /$ BW in Sham-operated animals at postoperative d 3, 4, and 7 in $\mathrm{NaD}$ animals and at postoperative $\mathrm{d} 4$ and 7 in Con animals $\left({ }^{*} p<0.05\right)$. Compensatory growth of the right lung after PNX was slower in $\mathrm{NaD}$ rats, inasmuch as the values for right $\mathrm{LW} / \mathrm{BW}$ in this group are significantly less than the combined LW/BW in Sham operated animals at all postoperative time points studied $(\dagger p<0.05)$. This is in contrast to the Con group, where right $\mathrm{LW} / \mathrm{BW}$ was not different from the combined LW/BW from Sham operated animals from $4 \mathrm{~d}$ postoperative.

extent. Dry right lung mass in Con-PNX animals was above Con-Sham values $3 \mathrm{~d}$ postoperative and was equal to Con-Sham combined lung mass by postoperative $\mathrm{d} 4$ (Table 1 ). In NaDPNX animals, right lung mass was increased as compared with NaD-Sham animals at postoperative $\mathrm{d} 3,4$, and 7 . The values for right lung mass were similar to those for both lungs of $\mathrm{NaD}$ Sham animals $4 \mathrm{~d}$ postoperative but significantly lower at $\mathrm{d} 7$. This apparent discrepancy in the pattern of lung growth can be explained by the fact that this particular group of NaD-Sham animals was smaller at the day of surgery (not shown), as well as on postoperative $\mathrm{d} 4$ (Table 1). When the lung growth is expressed in relation to $\mathrm{BW}$, this discrepancy disappears.

Postoperative changes in LW/BW are shown in Figure 1. In Con-PNX rats, right $\mathrm{LW} / \mathrm{BW}$ increased to equal that of both lungs (combined LW/BW) in Con-Shams by $4 \mathrm{~d}$ postoperative, and remained at the control value on $\mathrm{d} 7$. Compensatory growth of the right lung was slower in NaD-PNX animals. At postoperative $\mathrm{d} 4$, right $\mathrm{LW} / \mathrm{BW}$ was lower than combined $\mathrm{LW} / \mathrm{BW}$ of
NaD-Shams. Right LW/BW in NaD-PNX animals approached but did not reach the NaD-Sham value for combined LW/BW by postoperative $\mathrm{d} 7$.

RNA/g dry tissue and RNA/DNA in NaD lungs (Table 3) tended to be below the control in all groups, although the changes reached statistical significance only at postoperative d 3 (RNA and RNA/DNA) and 7 (RNA). During the rapid phase of compensatory growth (postoperative $\mathrm{d} 3$ and 4), both NaD and Con rats exhibited a $20 \%$ increase in tissue RNA concentration. Comparable protein/DNA ratios at $\mathrm{d} 4$ and 7 postoperative (Table 3), as well as elevated total DNA in the right lung of both PNX groups (not shown), suggest that the compensatory lung growth is hyperplastic rather than hypertrophic in both $\mathrm{NaD}$ and Con animals.

\section{DISCUSSION}

Partial pneumonectomy initiates compensatory growth of the remaining lung tissue in rats and a variety of other species. Multiple studies suggest that this compensatory response is rapid and is accomplished by cellular hyperplasia rather than hypertrophy. This experimental model has provided valuable insight into the mechanisms controlling both normal lung growth and the response of the lung to injury $(13,14)$. The rate and nature of postpneumonectomy lung growth are affected by hormonal influences as well as by age of the animal at the time of surgery. Our report documents that, in addition to other known modulators of the postpneumonectomy response, lung growth can be impaired secondary to sodium deficiency.

Our study provides confirmation that diet-induced sodium deficiency leads to growth failure in the rat. In a previous study using a similar nutritional protocol, Wassner (10) calculated sodium intakes of $25-115 \mu \mathrm{mol} / \mathrm{d}$ in $\mathrm{NaD}$ rats (normal $>300$ $\mu \mathrm{mol} / \mathrm{d}$ ), although they had comparable caloric intake relative to the Con animals. The somatic growth patterns as well as values for relative tissue RNA from that study closely parallel our results. New findings of our study are that the normal lung growth does not appear to be affected by sodium deficiency, whereas there is a slowing of the rapid compensatory lung growth in the $\mathrm{NaD}$ animals.

Caloric deprivation has been shown previously to decrease BW and to a lesser extent $\mathrm{LW}$, thus resulting in a slightly elevated $\mathrm{LW} / \mathrm{BW}$ ratio $(22,23)$. Lowered tissue concentrations of RNA in the lungs of starved animals are associated with a proportional inhibition of protein synthesis (22). Because tissue protein is accumulated in the lung in direct proportion to tissue mass, net protein synthesis is related directly to growth. Inasmuch as the bulk of tissue RNA is ribosomal, these results suggest that shortterm starvation leads to a limitation of the capacity of the lung to synthesize protein through a reduction in ribosomal availability and that this limitation is associated with deficient growth of the tissue. In contrast, when activity of the synthetic pathway is expressed on a per RNA basis, no change in translational efficiency is evident. In our study, experimentally induced reductions in tissue RNA concentration are qualitatively similar to those in the starvation model, although caloric deprivation was not imposed.

After partial pneumonectomy, a key aspect of the response in the remaining lung lobes is an elevation in RNA content and an associated increase in the overall rate of synthesis of lung proteins (17). If protein degradation is assumed to remain unchanged, this increase in protein synthetic capacity is sufficient to account entirely for the observed postoperative growth of the tissue. In $\mathrm{NaD}$ animals, a postpneumonectomy increase in RNA is preserved, even though tissue RNA concentration tends to be reduced during basal growth.

Our results with $\mathrm{NaD}$ animals demonstrate an effect on the time course of compensatory lung growth. A similar relationship between body growth rate and the time course of compensatory lung growth is also observed when more slowly growing older 
Table 3. Effect of sodium deficiency on right lung macromolecule concentrations*

\begin{tabular}{lcccccc}
\hline $\begin{array}{c}\text { Treatment } \\
\text { group }\end{array}$ & $n$ & $\begin{array}{c}\text { Days after } \\
\text { PNX }\end{array}$ & $\begin{array}{c}\text { DNA-P } \\
(\mathrm{mg} / \mathrm{g} \text { dry })\end{array}$ & $\begin{array}{c}\text { RNA } \\
(\mathrm{mg} / \mathrm{g} \text { dry })\end{array}$ & $\begin{array}{c}\text { RNA/DNA-P } \\
(\mathrm{mg} / \mathrm{mg})\end{array}$ & $\begin{array}{c}\text { Protein/DNA-P } \\
(\mathrm{mg} / \mu \mathrm{g})\end{array}$ \\
\hline Con & 6 & 0 & $2.88 \pm 0.05$ & $18.7 \pm 0.8$ & $6.49 \pm 0.27$ & $0.234 \pm 0.005$ \\
NaD & 6 & 0 & $2.72 \pm 0.07$ & $17.6 \pm 0.9$ & $6.46 \pm 0.25$ & $0.247 \pm 0.007$ \\
& & & & & & \\
Con Sham & 6 & 3 & $2.93 \pm 0.06$ & $16.6 \pm 0.2$ & $5.66 \pm 0.08$ & $0.234 \pm 0.005$ \\
Con PNX & 6 & 3 & $2.58 \pm 0.07 \ddagger$ & $18.3 \pm 0.4 \ddagger$ & $7.08 \pm 0.15 \ddagger$ & $0.256 \pm 0.007$ \\
NaD Sham & 5 & 3 & $2.94 \pm 0.08$ & $14.9 \pm 0.2 \dagger$ & $5.07 \pm 0.09 \dagger$ & $0.224 \pm 0.010$ \\
NaD PNX & 6 & 3 & $2.82 \pm 0.09$ & $17.7 \pm 0.5 \ddagger$ & $6.30 \pm 0.16 \ddagger$ & $0.247 \pm 0.006$ \\
Con Sham & 4 & 4 & $2.81 \pm 0.08$ & $15.1 \pm 0.6$ & $5.48 \pm 0.16$ & $0.226 \pm 0.014$ \\
Con PNX & 5 & 4 & $2.40 \pm 0.05 \ddagger$ & $18.3 \pm 0.9 \ddagger$ & $7.56 \pm 0.49 \ddagger$ & $0.267 \pm 0.020$ \\
NaD Sham & 5 & 4 & $2.87 \pm 0.04$ & $14.6 \pm 0.3$ & $5.11 \pm 0.15$ & $0.226 \pm 0.019$ \\
NaD PNX & 5 & 4 & $2.49 \pm 0.07 \ddagger$ & $17.4 \pm 0.4 \ddagger$ & $6.99 \pm 0.22 \ddagger$ & $0.242 \pm 0.010$ \\
Con Sham & 4 & & & & & \\
Con PNX & 5 & 7 & $2.42 \pm 0.06$ & $13.4 \pm 0.8$ & $5.53 \pm 0.25$ & $0.222 \pm 0.023$ \\
NaD Sham & 7 & 7 & $2.33 \pm 0.11$ & $15.2 \pm 0.3 \dagger$ & $6.56 \pm 0.24 \ddagger$ & $0.227 \pm 0.014$ \\
NaD PNX & 9 & 7 & $2.35 \pm 0.05$ & $11.8 \pm 0.3 \dagger$ & $5.04 \pm 0.14$ & $0.223 \pm 0.008$ \\
\end{tabular}

$*$ Values reflect mean \pm 1 SEM.

$+p<0.05 ; \mathrm{NaD}$ vs Con.

$\ddagger p<0.05$; PNX vs Sham.

rats are compared with rapidly growing younger animals (15, 24). Both age groups of animals again respond to lung resection with an increase in tissue RNA concentration. The slower course of the postpneumonectomy response in older animals reflects not only a slower rate of overall somatic growth, but also the fact that accretion of more tissue is required for completion of the response. In contrast, $\mathrm{NaD}$ rats, although demonstrating slower somatic growth relative to controls, have slightly smaller lungs and thus require the accumulation of less tissue to complete the response. Because a comparable percent increase in tissue RNA is seen after pneumonectomy in both $\mathrm{NaD}$ and Con animals, slower compensatory growth may reflect a reduced efficiency of protein synthesis. The relative difference in rates of compensatory right lung growth between $\mathrm{NaD}$ and control animals may thus be larger than suggested by the observed delay in achieving comparable LW/BW ratios. Additional studies in vitro are required to resolve this issue.

It is not clear why sodium deficiency has dramatic effects on growth in young rats. Although caloric intake is comparable in both groups, it is possible that calorie absorption is lowered in the NaD animals; however, no obvious evidence of malabsorption was noted in this group. It is also possible that the underlying metabolic rate is elevated in $\mathrm{NaD}$ animals as compared with controls. Both volume contraction and sodium restriction in adult humans leads to elevated plasma norepinephrine levels $(25$, 26). Catecholamines in general, and norepinephrine specifically, play a key role in determining energy expenditure and storage $(27,28)$. Sympathetic nervous system activity is suppressed by caloric restriction (28) and beta blockers decrease the thermogenic response to glucose (27). Conversely, elevated catecholamines stimulate thermogenesis (28). These observations may explain at least part of the decrease in weight gain per calorie consumed by $\mathrm{NaD}$ rats.

Although extrapolation of results from animal studies to clinical scenarios must be made with great care, the findings from our study may be especially relevant. Salt and water restriction as well as diuretics are commonly used in the management of infants with cardiopulmonary distress $(6-8)$. This is despite a great deal of controversy as to whether long-term outcome is altered favorably with this management $(7,8)$. At least one report describes a sodium deficit in infants on chronic furosemide therapy (9), but this subject has been studied little.

Perlman et al. (29) implicated chloride depletion as an important contributor to mortality in infants with bronchopulmonary dysplasia. Not surprisingly, this was closely associated with the administration of furosemide. Those investigators described hyponatremia as a less common finding than hypochloremia in their infants. The definition used, serum sodium $<130 \mathrm{mmol} / \mathrm{L}$, may not be a very sensitive index of total body sodium depletion. In an experimental model of sodium deficiency identical to that described herein, serum sodium was only slightly depressed (134 $\mathrm{mmol} / \mathrm{L} \mathrm{NaD}$ versus $139 \mathrm{mmol} / \mathrm{L}$ Con) despite otherwise dramatic evidence of sodium deficiency (10). If sodium deficiency has an effect on lung growth and differentiation, then it might be anticipated that diuretic therapy and sodium restriction could be counterproductive in the infant with chronic cardiopulmonary dysfunction. This issue deserves prospective evaluation.

In summary, young rats fed a diet deficient only in sodium demonstrated a significant delay of somatic growth relative to sodium sufficient controls. Sodium deficiency did not reduce normal lung growth during the intervals studied, however, $\mathrm{NaD}$ rats exhibited slower compensatory growth of the right lung after PNX. These findings suggest that sodium deficiency alters the ability of the rat to mount an appropriate compensatory growth response after partial resection of the lung.

Acknowledgment. The authors thank Dr. Ronald Poland for his careful reading of this manuscript.

\section{REFERENCES}

1. Avery ME, Tooley WH, Keller JB, Hurd SS, Bryan MH, Cotton RB, Epstein MF, Fitzhardinge PM, Hansen CB, Hansen TN, Hodson WA, James LS, Kitterman JA, Nielsen HC, Poirier TA, Truog WE, Wung JT 1987 Is chronic lung disease in low birth weight infants preventable? A survey of eight centers. Pediatrics 79:26-30

2. Frank L, Sosenko IRS 1988 Undernutrition as a major contributing factor in the pathogenesis of bronchopulmonary dysplasia. Am Rev Respir Dis 138:725-729

3. Frank L, Groseclose E 1982 Oxygen toxicity in newborn rats: the adverse effects of undernutrition. J Appl Physiol 53:1248-1255

4. Winick M, Noble A 1966 Quantitative changes in DNA, RNA, and protein during prenatal and postnatal growth in the rat. Dev Biol 12:451-466

5. Lechner AJ 1985 Perinatal age determines the severity of retarded lung development induced by starvation. Am Rev Respir Dis 131:638-643

6. Engelhardt B, Blalock WA, DonLevy S, Rush M, Hazinski TA 1989 Effect of spironolactone-hydrochlorothiazide on lung function in infants with chronic bronchopulmonary dysplasia. J Pediatr 114:619-624

7. Albersheim SG, Solimano AJ, Sharma AK, Smyth JA, Rotschild A, Wood BJ, Sheps SB 1989 Randomized double-blind, controlled trial of long-term diuretic therapy for bronchopulmonary dysplasia. J Pediatr 115:615-620

8. Patel H, Yeh TF, Jain R, Pildes R 1985 Pulmonary and renal responses to furosemide in infants with stage III-IV bronchopulmonary dysplasia. Am J Dis Child 139:917-919

9. Salmon AP, Finkel Y, Silove ED, Evans JA, DeGiovanni JV, Wright JGC, 
Booth IW 1989 Sodium balance in infants with severe congestive heart failure. [letter] Lancet 2:875

10. Wassner SJ 1989 Altered growth and protein turnover in rats fed sodium deficient diets. Pediatr Res 26:608-613

11. Fine BP, Ty A, Lestrange N, Levine OR 1987 Sodium deprivation growth failure in the rat: alterations in tissue composition and fluid spaces. $J$ Nutr 117:1623-1628

12. Rudman D, Millikan WJ, Richardson TJ, Bixler TJ, Stackhouse WJ, McGarrity WC 1975 Elemental balances during intravenous hyperalimentation of underweight adult subjects. J Clin Invest 55:94 104

13. Rannels DE, Rannels SR 1988 Compensatory growth of the lung following partial pneumonectomy. Exp Lung Res 14:157-182

14. Cagle PT, Thurlbeck WH 1988 Postpneumonectomy compensatory lung growth. Am Rev Respir Dis 138:1314-1326

15. Rannels DE, Burkhart LR, Watkins CA 1984 Effect of age on the accumulation of lung protein following unilateral pneumonectomy in rats. Growth 48:297308

16. Burri PH, Sehovic S 1979 The adaptive response of the rat lung after bilobectomy. Am Rev Resp Dis 1 19:769-777

17. Rannels DE, White DM, Watkins CA 1979 Rapidity of compensatory lung growth following pneumonectomy in adult rats. J Appl Physiol 46:326-333

18. Lowry OH, Rosebrough NJ, Farr AL, Randall RJ 1951 Protein measurement with the Folin phenol reagent. J Biol Chem 193:265-275

19. Manchester KL, Harris EJ 1968 Effects of denervation on the synthesis of ribonucleic and deoxyribonucleic acid in rat diaphragm muscle. Biochem $\mathrm{J}$ 108:177-183

20. Munro HN, Fleck A 1966. The determination of nucleic acids. Methods Biochem Anal 14:113-176

21. Snedecor GW, Cochran WG 1989 Statistical Methods. lowa State University Press, Ames, pp 217-236

22. Rannels DE, Sahms RH, Watkins CA 1979 Effects of starvation and diabetes on protein synthesis in lung. Am J Physiol 236:E421-E428

23. Lechner AJ 1985 Starvation-induced organ hypoplasia in prenatal and postnatal guinea pigs. Biol Neonate 48:36-42.

24. Holmes C, Thurlbeck WM 1979 Normal lung growth and response after pneumonectomy in rats at various ages. Am Rev Respir Dis 120:1125-1136

25. Lake CR, Ziegler MG 1977 Effect of acute volume alterations on norepinephrine and dopamine- $\beta$-hydroxylase in normotensive and hypertensive subjects. Circulation 57:774-778

26. Rosen SG, Linares OA, Smith MJ, Halter JB 1989 Down regulation of $\beta$ adrenergic receptor-mediated function during sodium restriction in humans. Am J Physiol 257:E499-E504

27. Sims EAH, Danforth E 1987 Expenditure and storage of energy in man. J Clin Invest 79:1019-1025

28. Landsberg L, Young JB 1983 The role of the sympathetic nervous system and catecholamines in the regulation of energy metabolism. Am J Clin Nutr 38:1018-1024

29. Perlman JM, Moore V, Siegel MJ, Dawson J 1986 Is chloride depletion an important contributing cause of death in infants with bronchopulmonary dysplasia? Pediatrics 77:212-216 